\title{
Artistic Innovation Development in the Management of Cultural, Traditional, and Festival Tourisms at Phu Hin Rong Kla, Phu Thab Boek, and Khao Khor
}

\author{
Jirawat Phirasant ${ }^{1}$ \\ ${ }^{1}$ Department of Art and Design, Faculty of Architecture, Naresuan University, Thailand \\ Correspondence: Jirawat Phirasant, Department of Art and Design, Faculty of Architecture, Naresuan University, \\ Thailand. E-mail: jirawat@sut.ac.th
}

\author{
Received: March 16, $2017 \quad$ Accepted: April 19, $2017 \quad$ Online Published: April 19, 2017 \\ doi:10.5539/ass.v13n5p176 URL: https://doi.org/10.5539/ass.v13n5p176
}

\begin{abstract}
The current research involves the development of artistic innovation in the management of cultural, traditional, and festival tourisms at Phu Hin Rong Kla, Phu Thab Boek, and Khao Khor. It aims to investigate the body of knowledge about the cultural, traditional, and festival tourist attractions in these three destinations; examines the potential of communities in developing tourism routes; develop and evaluates the development of artistic innovation in tourism management.

The researcher employed a mixed-methods approach which include a survey research of the communities within the 3 targeted areas, a qualitative investigation by means of observing the community participation, an in-depth interview, and social interaction as public network. The methodology includes an analysis of local database system, the development of a public model for an analysis of relation system, knowledge development of community people, relationship network, and the dynamics of community culture that supports tourism in the communities within the areas of Phu Hin Rong Kla, Phu Thab Boek, and Khao Khor. These 3 areas cover 2 provinces, 3 districts, 11 sub-districts, and 131 villages.

The development of artistic innovation in tourism management comprises 4 aspects namely: 1) Knowledge management includes electronic database system, E-Books and tourism documents; 2) Development of products and souvenirs includes survey and selection of community products and souvenirs, designing products and souvenirs, bazaar festival, and printed materials; 3) Public relations includes tourism guidebook, tourism maps and pamphlets, public relations through radio and TV, and printed materials; 4) Aesthetic value includes documentary film, songs, documentary photo book, Art Workshop, commercial ads, and Land Art. The summary results of evaluation of the overall quality by interviewing with 80 tourists and experts of tourism and art, suggested that the development of artistic innovation in the 3 aspects, i.e. knowledge management, public relations, and values were at a very high level, and development of products and souvenir was at a high level.
\end{abstract}

An evaluation of tourists' satisfaction towards the project operation was conducted using a questionnaire with a sample of 2,000 persons at post-implementation of the project and sub-activities. The results of evaluation suggested tourists' satisfaction at a high level $(X=4.17, \mathrm{sd}=0.81)$; income at a high level $(X=4.56, \mathrm{sd}=0.81)$; and increased number of tourists at a highest level $(\mathrm{X}=4.54, \mathrm{sd}=0.81)$.

The results also indicated that the artistic innovation on public relations can serve to draw the attention of tourists to visit particular tourist attractions for their aesthetic value, distinctive uniqueness, cultural, traditional, and historical significances, landscape, climate, way of life, and festivals in each area. More useful information include telephone number, website, maps, transportation, tourism information center, geographical and climatic conditions, and warning and alarm in each of the tourism attractions.

Keywords: Artistic Innovation, Tourism Management, Culture, Tradition, and Festival

\section{Introduction}

\subsection{Significance of the Problem}

The primary potentials of tourism in the areas of Phu Hin Rong Kla, Phu Thab Boek, and Khao Khor suggests the strengths in their diverse tourism activities and rich resources of tourism that attract tourists, however with an apparent weakness in terms of less integration among involved sectors including the government, the local 